\title{
10 An inventory of Turkey's international trade and investment agreements
}

(Note based on a paper by SUBIDEY TOGAN)

\section{Introduction}

Turkey has one of the largest economies in the Middle East. It also has a border with the European Union (EU) which is its main trading partner. As Table 10.1 shows, the EU accounted for more than half of Turkish exports while the share of Turkish imports from the EU was over 40 per cent at the beginning of the 1990s.

Turkey maintains long-standing trade and Association Agreements with the EU. However, the transition in the Central and Eastern European Countries (CEECs) and the creation of the Commonwealth of Independent States (CIS) has generated new options for Turkey's trade and investment policies. Furthermore, Turkey has a strong interest in the countries neighbouring the Black Sea.

This note presents an inventory of Turkey's international trade and investment agreements. These agreements were implemented in the context of Turkey's macroeconomic stabilization and export-promotion policies during the 1980s. During the 1990s economic reform focused in particular: (i) again on macroeconomic stabilization measures, and (ii) on the restructuring of state enterprises.

\section{Turkey-EU Agreements}

In 1963 Turkey signed an Association Treaty with the EU. This Treaty covers not only the issue of trade in manufactures but also trade in agricultural products, free movement of labour, freedom of settlement for 
professions, freedom of trade in services and capital transactions, and stipulations about the harmonization of tax systems and rules of competition. During the preparatory period, the EU granted unilateral concessions to Turkey in the form of financial assistance and preferential tariffs on traditional Turkish exports. Initially, Turkey did not have to change its trade regime.

Table 10.1 Trade between Turkey and the EU (in millions of U.S.\$ and in percentages)

\begin{tabular}{ccccc}
\hline \hline & $\begin{array}{c}\text { Turkey's } \\
\text { exports to the } \\
\text { EU }\end{array}$ & $\begin{array}{c}\text { Share of Turkey's } \\
\text { exports to the EU } \\
\text { in total Turkish } \\
\text { exports }\end{array}$ & $\begin{array}{c}\text { Turkey's } \\
\text { imports from } \\
\text { the EU }\end{array}$ & $\begin{array}{c}\text { Share of Turkey's } \\
\text { imports from the } \\
\text { EU in total } \\
\text { Turkish imports }\end{array}$ \\
\hline 1985 & 3,204 & 40.3 & 3,895 & 34.3 \\
1986 & 3,263 & 43.8 & 4,565 & 41.1 \\
1987 & 4,868 & 37.8 & 5,666 & 40.0 \\
1988 & 5,098 & 43.7 & 5,894 & 41.1 \\
1989 & 5,408 & 46.5 & 6,055 & 38.3 \\
1990 & 6,893 & 53.2 & 9,328 & 41.8 \\
1991 & 7,042 & 51.8 & 9,222 & 43.8 \\
1992 & 7,603 & 51.7 & 10,050 & 43.9 \\
1993 & 7,288 & 47.5 & 12,950 & 44.0 \\
\hline \hline
\end{tabular}

Source: EUROSTAT database.

The goal of an Additional Protocol to the Treaty which Turkey signed in 1973 was the establishment of a customs union. For its part, the EU agreed to abolish all customs duties, and also charges having equivalent effect on imports from Turkey. However, the EU retained the right to charge import duties on some oil products over a fixed quota, and to implement a phased reduction of duties on imports of some textile products from Turkey. Further, the EU was to provide some financial support, and there were provisions designed to ensure the free flow of labour by 1986. In exchange, Turkey agreed to: (i) reduce duties and other charges on imports; (ii) to eliminate the use of quota allocations; and (iii) to adopt the Common Customs Tariff of the EU, all in several stages. 
Exceptions to trade liberalization in textiles and clothing and agriculture were of particular importance. Furthermore, Turkish exports of iron and steel, which represent a large share of total Turkish exports to the EU, have occasionally been subject to anti-dumping duties. Exports of textiles and clothing came under the trade regime formulated in the Multi-Fibre Arrangement (MFA), while voluntary export restraint agreements (VERs) concluded between the Turkish textile exporters and the Brussels authorities were regulated under the Protocol. Since 1987 Turkish exports of agricultural products have been exempt from EU import duties but not from variable levies.

The implementation of the Protocol caused problems of adjustment, particularly in highly protected sectors. Nevertheless, the EU is committed to eliminate all its restrictions on imports of textiles and clothing from Turkey while Turkey has to eliminate its system of import levies. Furthermore, Turkey will apply all of the preferential trade agreements which the EU has concluded with LDCs. As LDCs are Turkey's competitors in some sectors, such as textiles and clothing, and processed food, preferential trade regimes with them may cause serious problems for Turkish industry.

The harmonization of agricultural policy requires that Turkey has to adapt its national agricultural policy to the EU Common Agricultural Policy (CAP). This means that Turkey will apply EU market regulations and price policy without taking part in the CAP. Turkey also has to harmonize its commercial legislation regarding competition policy, state support, anti-dumping legislation, intellectual and industrial property rights, and public procurement. Turkey has committed itself to making these adjustments without the benefit of financial privileges on the same scale as those enjoyed by EU Member States such as Greece, Portugal and Spain when they joined the EU.

The Protocol has not been implemented on schedule. Following changes in its internal political situation, Turkey applied for membership of the EU in 1987. At that stage, the EU decided that it would be inappropriate for it to become involved in new accession negotiations. The completion in 1995 of the customs union, in accordance with the provisions of the Agreement, was considered by the Commission of prime importance for increased interdependence and integration between Turkey and the EU. 


\section{Relations between Turkey and other organizations}

Turkey signed a free trade agreement with the EFTA states in 1991. The Agreement entered into force on 1 April 1992. According to this Agreement, Turkey will grant the same tariff reductions to imports from EFTA that it has granted to imports from the EU Member States, as well as operating the same time schedule of tariff reductions. Since 1 January 1993, Turkey has granted imports from the EFTA countries the same customs duty treatment as imports from the EU.

The idea of forming a Black Sea Economic Cooperation (BSEC) emerged in early 1990. A decision was reached to prepare a document containing the essential principles guiding economic cooperation in the region. In 1992, the final document was signed by the delegates of the nine participating countries (Armenia, Azerbaijan, Bulgaria, Georgia, Moldova, Romania, Russia, Turkey and Ukraine) and Greece, which joined later. The document stipulates cooperation in transportation, communications, energy, agriculture, mining, tourism, industry, medicine and the environment, as well as the establishment of a Black Sea Foreign Trade and Investment Bank. A permanent secretariat for the BSEC will be based in Istanbul. Until recently Turkey had very little trade with the post-Communist member states but this trade is expected to increase over time.

The 'Regional Cooperation for Development' (RCD) was founded in 1964 by Iran, Pakistan and Turkey. After a reorganization it was renamed the Economic Cooperation Organization (ECO). These countries decided to form a free trade area in 1976. Because of the political turmoil in the region this objective was not realized. In 1985 the countries decided to reshape the organizational structure of the RCD and cooperate in the framework of a 'preferential tariff arrangement'. Following the dissolution of the former Soviet Union, the newly-emerged republics of Central Asia (Azerbaijan, Kazakhstan, Kyrgyzstan, Tajikistan, Turkmenistan and Uzbekistan) applied for membership of the ECO. Their requests were granted at the Teheran meeting in February 1992.

The Organization of the Islamic Conference (OIC), founded in 1969, is composed of nearly 60 member countries. The countries include, among others, Afghanistan, Algeria, Bangladesh, Brunei, Egypt, Indonesia, Iran, Iraq, Jordan, Kuwait, Lebanon, Libya, Malaysia, Morocco, Pakistan, Saudi Arabia, Sudan, Syria, Tunisia, the United Arab Emirates and the newly independent Central Asian States. OIC is mainly a political forum rather than a regional economic organization. 


\section{Turkey-Central Asia and Turkey-Azerbaijan}

Although Azerbaijan is a member of BSEC and of ECO, and Kazakhstan, Kyrgyzstan, Turkmenistan and Uzbekistan are members of ECO, these countries are different from the other members of BSEC and ECO because of the close cultural ties they have with Turkey. In the past, the entire area covered by the Central Asian Republics was referred to as 'Turkestan' and recognized as a cultural unit. In Central Asia today, except for the Republic of Tajikistan which is Persian speaking, all the republics are Turkic by language and culture, and Turkey has long been the cultural magnet for Turkestan even in the nineteenth century. Similar considerations apply also to Azerbaijan, despite the Shiite religious link of this country with Iran.

The Turkic republics have a growing interest in contacts with Turkey, and seek investment and closer cultural ties. After the formal break-up of the former Soviet Union in December 1991, Turkey has reciprocated this interest. High-level visits accompanied the extension of formal recognition to the republics and the consequent diplomatic manifestations. Since 1991 Turkey has signed over 160 protocols and cooperative agreements and it has pledged more than U.S.\$1.2 billion in export credits to build infrastructure ties in transport and telecommunications, to extend financial and business contacts and to reinforce cultural relations.

\section{Protocol relating to trade negotiations amongst LDCs}

Turkey acceded to GATT in 1951 under the Torquay Protocol and has participated in all subsequent rounds of multilateral trade negotiations. It has accepted the Multilateral Trade Negotiations (MTN) Agreements on Subsidies and Countervailing Measures and on Customs Valuation. It has observer status in other MTN code committees including the Committee on Technical Barriers to Trade, the Committee on Anti-Dumping, the Committee on Government Procurement and the Committee on Import Licensing. Turkey is also a signatory to the Arrangement regarding International Trade in Textiles and to the GATT Protocol Relating to Trade Negotiations Amongst Developing Countries of 1971. Under this Protocol, Turkey gave concessions on about 66 items, with a preferential margin varying between 2 to 22 per cent on MFN rates. Most of these concessions no longer provide any effective preferential margins. 
In 1992, Turkey's imports from other members of the protocol amounted to only U.S.\$ 74.8 million.

\section{REFERENCES}

Low, P. (1992) 'The International Setting', paper presented at the Conference on Competition Policies for Turkey, Istanbul.

State Planning Organization (1994), Report on Globalization, Regional Integration and Turkey, Ankara.

\section{Discussion}

ZHOU SJIJIAN

From Chapter 10 by Togan it is clear that the EU-Turkey trade Agreements have had a positive impact on the welfare of Turkish citizens as witnessed by the increase of GNP per capita. Because of the trade liberalization in the early 1980s, Turkey's foreign trade has developed fast. With the opening policies and following the rules of GATT (now the WTO), the economy of Turkey, especially the foreign trade sector, should continue to grow.

Togan also stresses the fast development of regional economic groupings in recent years. We hope that the establishment of regional economic and trade blocks can coexist with global multilateral trade norms and that they will not become exclusive protectionist organizations. From this point of view, China adopts a positive attitude toward the enhancement of Asia Pacific Economic Cooperation. We believe that economic cooperation of the Asia Pacific area should adhere to the principles of mutual respect, equality under mutual benefit and reciprocal opening under common prosperity and we are not in favour of trade protectionism. Promotion of Asia Pacific Economic Co-operation should be based on strengthening global multilateral trade systems and should contribute to world economic growth. 